\title{
A BRAZILIAN SITE WITH ACTIVITIES FOR TEACHING STATISTICS
}

\author{
Marcos Nascimento Magalhães, Guilherme dos Santos Batista, Marco Aurélio Pereira da Silva \\ Universidade de São Paulo, Brazil \\ marcos@ime.usp.br
}

We describe the site AtivEstat- Atividades de Estatistica (Statistics activities) that is being developed at University of Sao Paulo, Brazil. The site aims to organize existing or new activities to assist in the teaching of statistics at all levels. The site contains a list of other sites and a set of activities. The main contribution of the site is to offer an organized material in Portuguese language that covers statistics topics for all teaching levels. An important challenge is to enlarge the number of teachers that promote possibilities of active learning in their classes and, consequently, in the teaching-learning of statistics. We think AtivEstat is an important tool, in this challenge.

\section{INTRODUCTION}

Since the 1990s, the Brazilian Federal Government has introduced guidelines for the basic education system through the National Curricular Parameters- NCP (Brasil, 1998/2002). There are also suggestions to prove the teaching-learning processes of statistics, which is included as a topic in mathematics courses. In this way, in Brazilian middle and high schools, basic Statistics concepts are taught by mathematics teachers that, usually, have a degree in Mathematics Education or in Physics and Science. To obtain their degree these teachers may have taken one or two statistics courses in the curricula. Despite this, most teachers do not feel comfortable to teach statistics issues. For an overview of statistics presence in Brazilian basic education, one can refer to Campos et al. (2011), Lopes et al. (2010) and Coutinho (2013).

At undergraduate level, several careers have statistics courses in their curricula. In general, at the public universities, these courses are taught by professors with a $\mathrm{PhD}$ degree in Statistics or close knowledge areas (see Louzada et al., 2010). In this case, it is supposed professors have no difficulties with statistics contents to teach, however due to the pressure to research papers publishing, the central focus might not be on classroom teaching-learning improvement.

The web provides a huge amount of information. The major concern is how to select contents teachers are looking for. It is necessary time and knowledge to do an adequate selection from the available material. Also, the language could be an important restraint in this issue.

In order to accomplish the task of better statistics courses at any level, statistics education researches have produced, and continuing to do, several suggestions as mentioned in Garfield \& Ben-Zvi (2008) and Salcedo (2013). Among them, illustrating concepts and using numbers in real context, providing an adequate environment, are important issues to improve statistical knowledge, as well as to enhance motivation and students' participation in the learning process.

In this direction, the website AtivEstat-Atividades de Estatistica (Statistics Activities) is being developed at Mathematics and Statistics Institute- University of Sao Paulo (IME-USP), Brazil. The site is directed mainly to teachers which we expect to have some familiarity with the subject, since there is no formal discussion of statistics concepts. Even though students' knowledge is the final objective, all writing of the site is directed to teachers, not to students.

The team that developed the site consists of two students, supported by a fellowship, and the coordinating professor. Neither of them has computer expertise, so the computational job was developed by the IME-USP staff. For the students in the team, the site development was an important learning experience, since they had to look to dozens of sites and activities in order to evaluate them, to decide on their inclusion, or not, in the site. It is important to mention that, among others, international sites as CensusAtSchool and CAUSE and Brazilian sites as IBGE (Vamos Contar) and AVALE were, and still are, sources of motivation and inspiration to our work (see sites addresses after References). At the moment, it is available an initial version of the site that still needs to evolve contents and layout. Next sections present more details of the site.

In: M.A. Sorto (Ed.), Advances in statistics education: developments, experiences and assessments. Proceedings of the Satellite conference of the International Association for Statistical Education (IASE), July 2015, Rio de Janeiro, Brazil. 


\section{NEW SITE TO STATISTICS CLASSES}

The site AtivEstat (www.ime.usp.br/ativestat) contains a list of related sites and a set of activities. In order to help users to choose adequate material in the listed sites, we included a brief description of their contents. Also, for each activity in the site, information is provided to help the user to choose activities related to the education level and the topic covered. To set activities to different education levels, we are based on the National Curricular Parameters- NCP (Brasil, 1998/2002), and Magalhães \& Lima (2013), respectively, for basic school and college levels.

Activities were included in AtivEstat after research and the selection in several internet portals. They were chosen according to topic, accuracy concepts, simple implementation and adaptation to Brazilian contexts. Activities, either come from other sites, or were created by the team members. For activities from other sites, AtivEstat shows the respective links in order users can access the original sources. Also, some activities were adapted concerning Brazilian daily life.

The activities are organized into topics, education levels and types of activity. Four statistical topics are considered: Tables and Graphs, Summary Measures, Probability and Models, and Statistics Inference. It is possible to use an activity in different teaching levels, and also some activities could to be related to more than one statistical topic. Educational levels are divided into Elementary and Middle schools, High school and College. Five types of activities, detailed ahead, are considered: Classroom use; Spreadsheets; Project proposals; Films and videos and Applets.

In the initial page of AtivEstat there is an introductory text for teachers, describing the portal main objectives and contents. At the top left we can find three icons that give the main structure, Activities, Related sites and Contact us/ Team. Figure 1 shows this page:

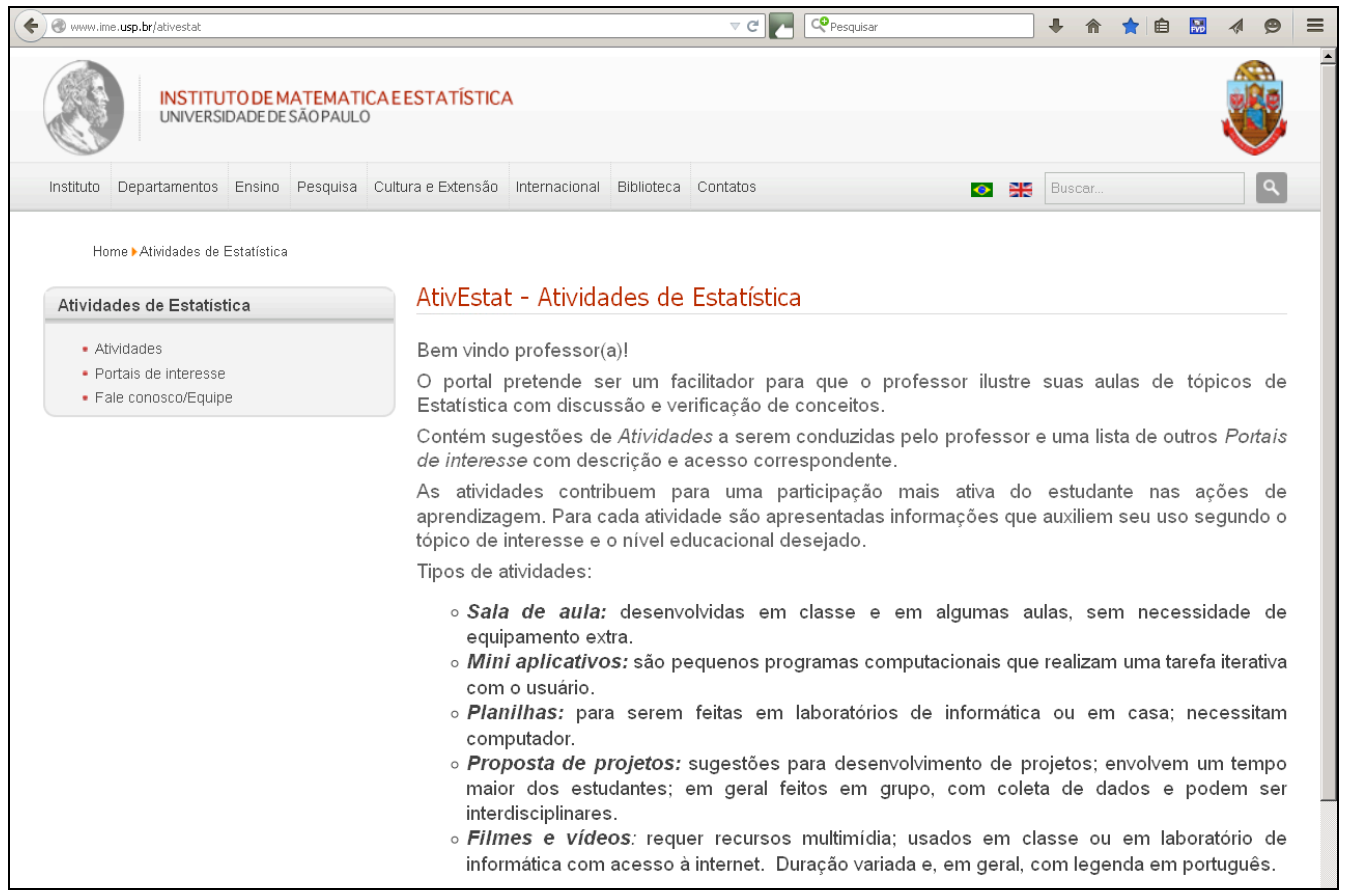

Figure 1. Initial page of AtivEstat

\section{SITE ATIVESTAT- ACTIVITIES}

Moving to Activities icon in initial page of AtivEstat, we access the page showed on Figure 2. In this page one can choose filter by topic, educational level or type of activity. A click on topic or educational level shows a list of activities separated by type.

An important AtivEstat feature is to provide information in Portuguese language on the activities, even if they are written in other languages. The kind of information presented in the site depends on the activity type. Next, we present details for each activity type. 


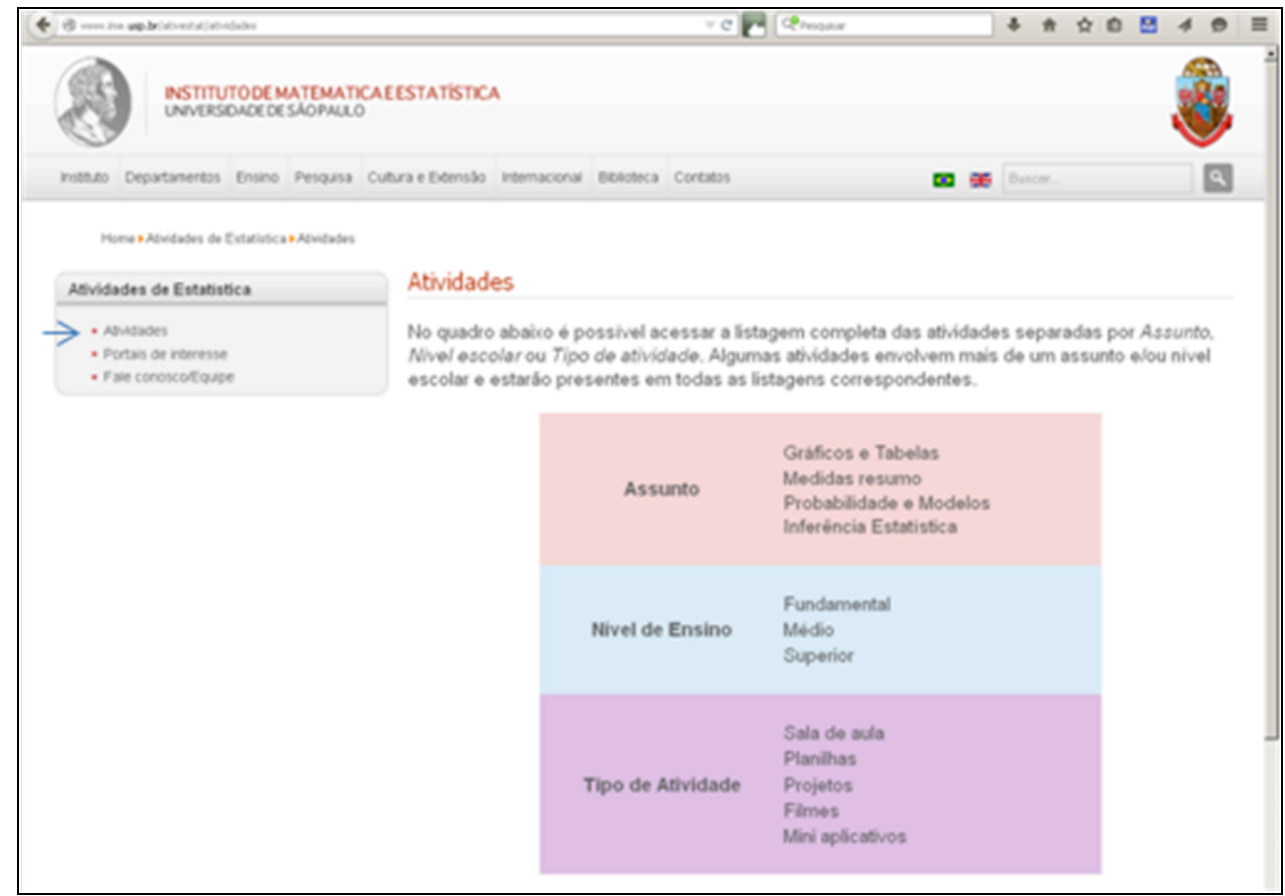

Figure 2. Activities page

\section{Classroom use}

These activities are intended to spend few hours, in general completed in one or two regular class meetings. They use simple material resources as paper cardboard, colored balls, boxes, ruler, and colored pens. Hitting Sala de aula, in the Activities window, it will appear a list of all activities of this type. There is an activity code, its name and a link to a window with the activity description (descrição in Portuguese). Figure 3 shows an example referred to activity SA09: Carlinha random walk (description).

\begin{tabular}{|l}
\hline SA09: Passeios aleatórios de Carlinha (descrição) \\
$\qquad \begin{array}{l}\text { SA09: Passeios aleatórios de Carlinha } \\
\text { Tópicos: Gráficose Tabelas, Probabilidade e Modelos. } \\
\text { Recursos: moedas, canetas coloridas, laboratório de informática } \\
\text { (opcional). } \\
\text { Nível de ensino: Fundamental e Médio. } \\
\text { Duração: } 4 \text { horas-aula. } \\
\text { Resumo: } \\
\text { É uma proposta do projeto AVALE (Ambiente Virtual de Apoio ao } \\
\text { Letramento Estatistico) para estimular os estudantes a compreender } \\
\text { probabilidade. Carlinha quer visitar seus amiguinhos, mas só pode se } \\
\text { mover para o norte ou para o leste. Cada movimento é decidido pelo } \\
\text { lançamento de uma moeda (que é assumida como equilibrada). } \\
\text { Dependendo das direçőes escolhidas em cada movimento, ela consegue } \\
\text { visitar um dos seus amigos. No desenvolvimento da atividade, os } \\
\text { estudantes fazem experimentos simulando o passeio e constroem gráficos } \\
\text { e tabelas com a frequência relativa. Ao final da atividade está previsto } \\
\text { formalizar os conceitosprobabilisticos envolvidos. } \\
\text { Mais detalhes: } \\
\text { http://ambiente.educacao.ba.gov.br/conteudos/download/1622.pdf }\end{array}$ \\
\hline
\end{tabular}

Figure 3. Description for Classroom use type of activity 
As showed in Figure 3, for this type of activity, the description includes Topics, Resources, School level, Duration, Summary and More details. In this case, More details brings a link to AVALE site to get more information to apply the activity. There are cases in which we produced a pdf file with additional information and that link will pointed at it.

\section{Spreadsheets}

For these activities type, it is necessary to use computers, either at home or in a lab. The tasks inserted will explore resources present in spreadsheets of commercial or free software. The activities provide students context to obtain graphs, calculate measures and perform simulations using random numbers generation. AtivEstat brings in Spreadsheets type, the same kind of information presented in Classroom use type of activity.

\section{Project proposals}

As the name indicates, these activities were thought to bring students' suggestions for group work using statistical tools. The Projects suggested may take several weeks with tasks in and out classroom environment and they also could provide an interaction with other disciplines. Also, for each Project proposals activity, AtivEstat presents similar information as the ones in Classroom use type of activity.

\section{Films and videos}

Films can motivate students in several statistical issues. For each film listed, there is a link with internet address. Also a description is provided. Besides the usual information, in this case, the description includes language and suggestion how to use the films, class organization and questions to be focused on. Figure 4 shows an example, FV15: Each graph in your branch tree (link, description).

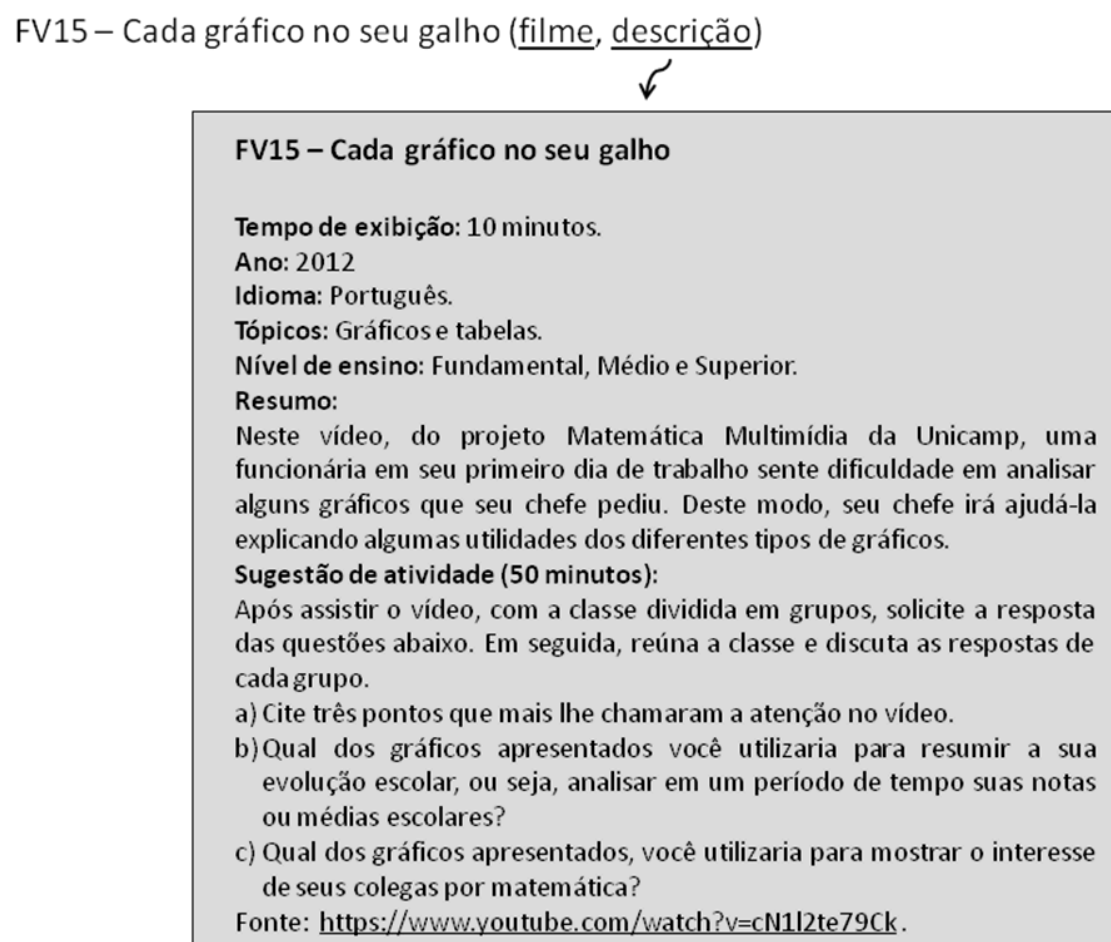

Figure 4. Description for Films and videos type of activity 
Applets

These activities use small computer programs to illustrate concepts, to draw graphs, and to measure calculations. They allow important statistical concepts discussions, saving time from calculations and manual draws. For each Applet, a summary and internet address is provided.

\section{SITE ATIVESTAT- RELATED SITES}

By clicking the second icon from the initial page of AtivEstat, we reach a page with a list of several portals. The list contains most of the sites sources used to build AtivEstat. The list helps teacher's pursuit of other activities and also serves as an outreach page of the different sites on Statistics. AtivEstat, first, lists Portuguese, then Spanish and finally, English sites. Within the available languages, the sites were listed in alphabetical order. Figure 5 shows this current page in AtivEstat.

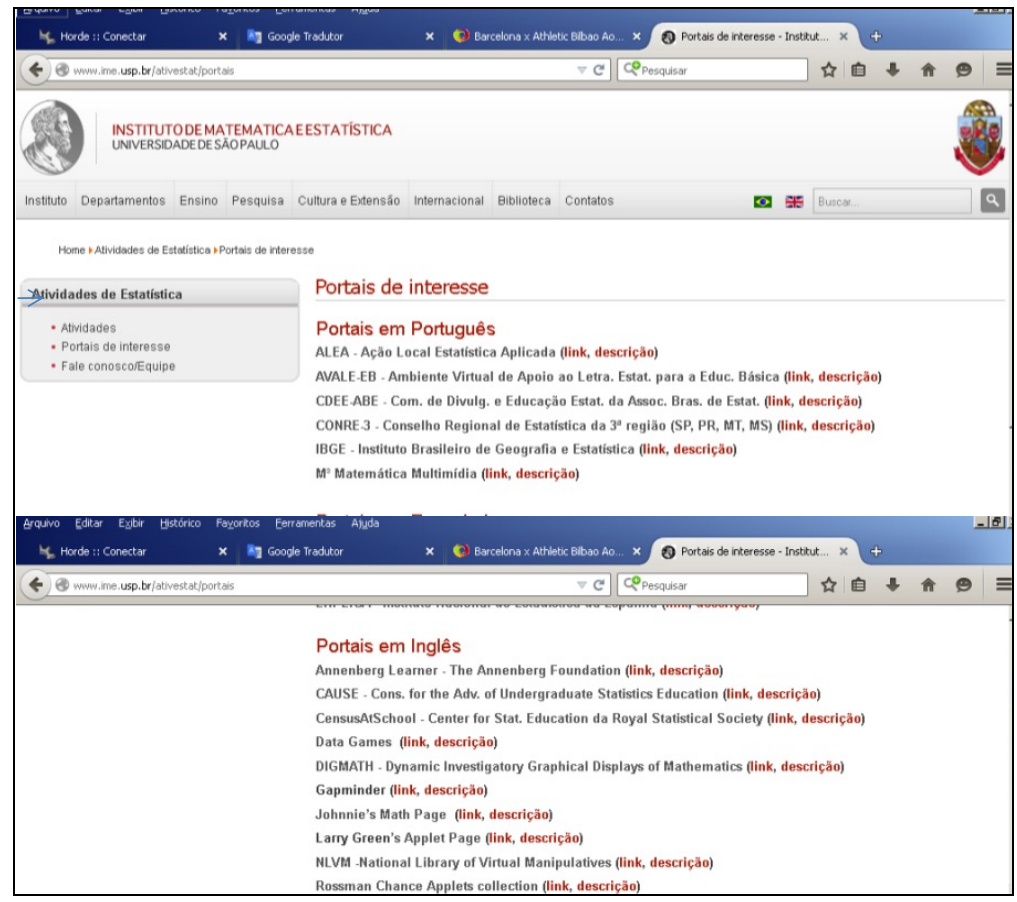

Figure 5. Related sites in AtivEstat

\section{CONCLUSION}

This new Brazilian site AtivEstat presents a description of activities and related sites to help teachers in their statistics classes, in Portuguese language. Division by categories of educational level and statistical topics intended to facilitate its use by teachers. However, it is quite common an activity to be applied in different levels or to be included into two statistical topics. So, classification must be seen as a guide to search, not a strict rule.

The inclusion of sites and activities in AtivEstat site will be a continuous process. The current version must be understood as a starting point, we realize that still remain important contributions to be incorporated in the sequence. Some of the activities already selected, were not included yet, because they are still in a construction process, since identified a site or an activity to be included, it is necessary to write the respective information in the correspondent format.

We realize there are a lot to do in order to improve the site layout and contents. Besides, we intend to create a collaborative relation with statistics teachers, from all educational levels, around the country, to obtain not only critical opinions but also new ideas to add to the site. To stimulate teachers, particularly the ones from basic schools, to use the site, we intend to promote workshops discussing statistical concepts and spreading out AtivEstat.

Finally, we would like to thank the Dean of Undergraduate Studies and the Dean of Culture and Extension, both from USP, for the financial support, through fellowships for students' team members. We also acknowledge the computational work support by the staff of IME-USP. 


\section{REFERENCES}

Brasil (1998). Secretaria de Educação Fundamental. Parâmetros Curriculares Nacionais Matemática ( $5^{\mathrm{a}}$ a $8^{\mathrm{a}}$ série e Ensino Médio). Brasília: MEC/SEF.

Brasil (2002). Secretaria de Educação Média e Tecnológica. PCN+ Ensino Médio: Orientações educacionais complementares aos Parâmetros Curriculares Nacionais. Brasília: MEC.

Campos, T. M. M., Cazorla, I. M., \& Kataoka, V. Y. (2011). Statistics School Curricula in Brazil. In C. Batanero, G. Burril, and C. Reading (Eds.), Teaching Statistics in School MathematicsChallenges for Teaching and Teacher Education: A Joint ICMI/IASE Study,(pp. 5- 8). New York: Springer Science+Business Media.

Coutinho, C. Q. S., ed. (2013). Discussões sobre o ensino e aprendizagem da Probabilidade e da Estatística na escola básica [Teaching and Learning discussions on Probability and Statistics in basic school]. Campinas: Mercado de Letras.

Garfield, J. B., \& Ben-Zvi, D. (2008). Developing students statistical reasoning: Connecting research and teaching practice. New York: Springer.

Lopes, C. E., Coutinho, C. Q. S. \& Almouloud, S. A., eds. (2010). Estudos e Reflexões em Educação Estatística [Study and Reflections on Statistics Education]. Campinas: Mercado de Letras.

Louzada, F., Ara, A., Oliveira, C. Z., \& Gonçalves, C. V. (2010). Diagnóstico do Ensino da Estatística nas Universidades Públicas Brasileiras: uma descrição de algumas dimensões que compõem o perfil do seu corpo docente [Diagnostic of teaching statistics in Brazilian public universities: description on dimensions about profile of their faculty staff]. Revista Brasileira de Estatística- IBGE, 71(234), 7-42.

Magalhães, M. N., \& Pedroso de Lima, A. C. (2013). Noções de Probabilidade e Estatística [Probability and Statistics notions], 7th ed., 2nd reprint- reviewed. São Paulo: Edusp.

Salcedo, A., ed. (2013). Educación Estadística em America Latina: Tendencias y Perspectivas. Acess: http://saber.ucv.ve/jspui/handle/123456789/4666,2013.

\section{SITE ADRESSES}

AVALE: http://avale.iat.educacao.ba.gov.br/

CAUSE: https://www.causeweb.org/

CensusAtSchool: http://www.censusatschool.org.uk/international-projects

IBGE (Vamos Contar): http://www.ibge.gov.br/home/ 